\title{
Jovellanos y la naturaleza: economía, ciencia y sentimiento
}

\author{
José Luis Ramos Gorostiza \\ Universidad Complutense de Madrid (UCM)
}

CES.XVIII, núm. 18 (2008), págs. 119-145. 
RESUMEN: Jovellanos, al que es difícil evaluar sólo como un mero economista con olvido del conjunto de su obra, fue uno de los ilustrados españoles que mayor atención prestó a la naturaleza. En sus polifacéticos escritos se dan cita nuevas y viejas concepciones sobre la relación hombre-naturaleza, reflejando en buena medida los importantes cambios que se produjeron a este respecto en Europa a lo largo del siglo XVIII. En principio, la actitud frente a la naturaleza del Jovellanos economista difiere de la del aficionado a las ciencias naturales, o de la del literato y el viajero. En este trabajo se analiza si los diversos planteamientos del asturiano en este terreno son compatibles o, por el contrario, resultan ser contradictorios.

Palabras clave: Jovellanos. Historia del pensamiento económico. Naturaleza. Economía. Gestión de recursos naturales.

Este trabajo se publicó originalmente en Scripta Nova. Revista Electrónica de Geografía y Ciencias sociales, Barcelona, Universidad de Barcelona, 15 de junio de 2007, vol. XI, núm. 241, 〈http://www.ub.es/ geocrit/sn/sn-241.htm> [ISSN: 1138-9788]. 


\section{Introducción}

En el siglo XVIII se producen cambios importantes en las ideas sobre la relación del hombre con la naturaleza, conviviendo al tiempo viejas y nuevas concepciones. Tal situación de cambio y pluralidad se va a manifestar en buena medida en la obra de Jovellanos (1744-1811), uno de los ilustrados españoles que mayor interés mostró hacia la naturaleza y que más páginas le dedicaron. La gran diversidad de su obra, que refleja a su vez las múltiples facetas del asturiano (economista, poeta, viajero, jurista, aficionado a las ciencias, etc.), hace que si se consideran aisladamente sus distintas partes — por ejemplo, los escritos económicos - se pueda obtener una imagen distorsionada de su pensamiento, en particular de su compleja actitud hacia la naturaleza. Y es que, como ha señalado Vicent Llombart ${ }^{1}$, es difícil evaluar a Jovellanos como «un mero economista sin más» con olvido del conjunto de su obra, pues hay en ella una intencionalidad unitaria o convergente a pesar de su carácter polifacético.

Por una parte, el interés de Jovellanos por la naturaleza fue, efectivamente, el del economista que no sólo conoce bien las labores agrícolas y los problemas de la agricultura, sino que también se ocupa de la explotación de las minas de carbón en Asturias, de la situación de la pesca en el Principado, o de la posibilidad de abrir vías de comunicación a través de una orografía complicada. Pero por otra parte está el interés científico, el del aficionado a las ciencias naturales que está al tanto de los avances en este terreno y que muestra un notable conocimiento en la materia movido por la curiosidad intelectual hacia las «maravillas del mundo natural». Finalmente, hay también un Jovellanos que se deja llevar por el sentimiento estético y que exalta las bellezas de la naturaleza e incluso sus valores espirituales, acuñando una nueva mirada hacia el paisaje que anticipa la visión romántica. El primero es el Jovellanos de obras como el Informe de ley agraria (1795), el «Discurso dirigido a la Sociedad de Amigos del País de Asturias sobre los medios de promover la felicidad de aquel Principado» (1781), o las diversas cartas e informes sobre minas. El segundo es, entre otros,

1 Vicent Llombart, «Estudio introductorio», en Gaspar Melchor de JovelLanos, Escritos económicos, Madrid, Real Academia de Ciencias Morales y Políticas, 2000, págs. 3-177, págs. 20-21. 
el Jovellanos de la «Oración sobre el estudio de las ciencias naturales» (1799) o del «Discurso sobre la geografía histórica» (1800). Y el tercero es el Jovellanos viajero del extenso Diario (1790-1808) —al que también se asoman a veces el economista y el científico aficionado-, el cautivo que redacta la «Descripción del Castillo de Bellver» (1806), o el joven escritor de obras literarias tales como la «Epístola a Batilo» (1782) o la «Epístola de Fabio a Anfriso».

Los escritos del Jovellanos economista reflejan la actitud predominante durante la centuria ilustrada en la relación Hombre-Naturaleza, la cual es esencialmente un producto novedoso del propio siglo XVIII: la marcada actitud de dominio y control del medio físico, desde la conciencia de que el hombre es un poderoso agente de cambio de su entorno natural y actúa sobre él hermoseándolo y eliminando los obstáculos que se oponen al progreso. Es decir, el trabajo del hombre y su intervención sobre el medio — desecando pantanos, construyendo obras de riego, aclarando bosques para realizar nuevas roturaciones, etc.contribuye a mejorarlo y hace desaparecer además las trabas que dificultan las posibilidades productivas. En definitiva, el hombre se enseñorea de la Tierra para hacerla más fecunda y bella, al tiempo que toda transformación de la naturaleza se justifica sobre la idea de progreso económico y capacidad productiva. De aquí deriva además un claro optimismo en relación a la disponibilidad y uso de los recursos naturales.

Los escritos del Jovellanos aficionado a las ciencias naturales, creador del Real Instituto Asturiano de Náutica y Mineralogía (1794), están a medio camino entre los del economista y los del literato en su visión de la naturaleza. Por una parte, como en el «Elogio a Carlos III» (1789), a veces dejan traslucir la concepción — propia de la Ilustración — del «conocimiento útil» al servicio del progreso, esto es, la idea de que el mejor conocimiento de la realidad física a través de la razón es la base para la mejora del aprovechamiento económico de los recursos naturales, y que por tanto puede contribuir al desarrollo de las actividades productivas y a la prosperidad general. En suma, la ciencia, al ser capaz de explicar el funcionamiento de la naturaleza por medio de leyes objetivas, facilita el dominio y control de la Tierra por el hombre en su propio provecho. Por otra parte, sin embargo, los escritos jovellanistas relativos a las ciencias naturales reflejan esencialmente un respeto reverencial hacia «las maravillas del mundo natural» inexistente en los textos del Jovellanos economista, pues se enmarcan en la vieja tradición providencialista, combinada con un renovado antropocentrismo y con la idea de orden y armonía de la naturaleza: todos los elementos del medio natural (animales, plantas, montañas, mares, etc.) — creados por Dios y reflejo de su providencia - obedecen al designio del Creador, cuyo principal propósito es el mantenimiento y la felicidad del hombre, señor de la naturaleza y centro 
del mundo. Asimismo, el funcionamiento de la naturaleza refleja la armonía del orden divino, y el optimismo respecto al mundo físico-natural y los recursos que éste brinda al hombre no deriva tanto de la firme creencia en el poder y la industria humana, sino de la fe en la Divinidad que guía el mundo como algo perfecto y completo.

Por último, aparece el Jovellanos que muestra una sensibilidad prerromántica ante la belleza natural que conecta con Rousseau. Frente al Jovellanos economista que admira la naturaleza recreada y domesticada por el hombre, uniendo siempre la idea de fertilidad a la de belleza, éste otro encuentra una belleza sublime en la naturaleza incontrolada: las montañas escarpadas, los mares revueltos y los alborotados cursos de agua. Esta incipiente idealización estética de los paisajes —incluso sacralización de la naturaleza- que se produce en los escritos de algunos ilustrados como Meléndez Valdés o el propio Jovellanos, conecta claramente con la sensibilidad romántica, la cual se acabaría convirtiendo en una de las raíces del conservacionismo moderno que reivindica la preservación del medio físico. En muchos textos del Jovellanos literato y viajero encontramos la misma actitud providencialista y reverencial hacia la naturaleza que en el Jovellanos aficionado a las ciencias, pero ahora la admiración la suscita simplemente la belleza estética en vez de los diversos aspectos de interés científico — como las complejas interrelaciones del mundo natural, su infinita variedad o las curiosas formas de organización existentes en el reino animal-. Además, en la mirada hacia la naturaleza del Jovellanos prerromántico no se da el componente utilitario que se observa en la mirada del aficionado a las ciencias.

Las tres aproximaciones a la naturaleza que se han señalado anteriormente son diferentes y a priori parecen tener implicaciones distintas. Sin embargo, no se corresponden con etapas sucesivas de la obra de Jovellanos, sino que se dieron de forma simultánea en escritos de una misma época. El objetivo de este trabajo es precisamente analizar en qué medida la visión de la naturaleza del Jovellanos economista es compatible con la que se plantea en los textos del aficionado a las ciencias o en algunos de los escritos del viajero y el literato. Lo que se pretende examinar, en definitiva, es si el asturiano fue consistente en su actitud hacia la naturaleza o si por el contrario sus diversos planteamientos en este terreno resultan contradictorios.

II. La naturaleza en el Jovellanos economista: progreso y sometimiento del medio

Hay un famoso fragmento del Informe de ley agraria (1795) en el que el Jovellanos economista deja nítidamente definida su actitud frente a la naturaleza: 
Aunque el oficio del labrador es luchar a todas horas con la naturaleza, que de suyo nada produce sino maleza, y que sólo da frutos sazonados a fuerza de trabajo y cultivo, hay sin embargo en ella obstáculos tan poderosos que son insuperables a la fuerza de un individuo, y de los cuales sólo pueden triunfar las fuerzas reunidas de muchos. La necesidad de vencer esta especie de estorbos, que acaso fue la primera a despertar en los hombres la idea de un interés común y a reunirlos en pueblos para promoverlo, forma todavía uno de los primeros objetos y señala una de las primeras obligaciones de toda sociedad política².

Al igual que Cabarrús en la primera de sus Cartas, la naturaleza es contemplada aquí por Jovellanos esencialmente como una fuente de obstáculos físicos al progreso económico, unos estorbos tan poderosos que a menudo sólo la acción colectiva puede vencer ${ }^{3}$. Adam Smith, que había colocado al factor trabajo en el centro mismo de la creación de riqueza, consideraba que «en la agricultura la naturaleza trabaja junto al hombre» ${ }^{4}$, quien más que animar su fertilidad, la regulaba y dirigía en su propio provecho. Pero Jovellanos, yendo un poco más allá, pone todo el acento en el esfuerzo humano: la naturaleza «nada produce sino maleza», y sólo la acción humana parece hacer fecunda la tierra a fuerza de lucha y combate constantes del agricultor con el medio natural, al que al fin somete haciéndole dar «frutos sazonados». Es decir, la relación del hombre con la naturaleza se establece en términos de enfrentamiento, que finalmente se resuelve en el dominio de ésta por aquél. De dicho dominio surge una naturaleza mejorada, bella, útil, donde lo que resulta admirable no es la naturaleza en sí, sino los resultados de la industria y la laboriosidad humanas al intervenir sobre el entorno:

Sin duda que a [la acción del hombre] debe la naturaleza grandes mejoras. A doquiera que se vuelva la vista, se ve hermoseada y perfeccionada por la mano del

2 Gaspar Melchor de Jovellanos, «Elogio de Carlos Tercero [1789]», en Escritos económicos, Madrid, Real Academia de Ciencias Morales y Políticas, 2000, págs. 477-495.

3 Francisco Cabarrús, Cartas sobre los obstáculos que la naturaleza, la opinión y las leyes oponen a la felicidad pública (1792), Fundación Banco Exterior, Madrid, 1990, págs. 47-71. No es casual que las Cartas, redactadas entre 1793 y 1794, aborden el problema de los obstáculos físicos de forma similar al Informe de Ley Agraria de Jovellanos, pues tienen un origen relacionado con éste. De hecho, las Cartas no son más que diferentes comentarios a un borrador del Informe que Jovellanos suministró a Cabarrús antes de terminarlo, Vicent LlombarT «El pensamiento económico de la Ilustración en España», en Enrique Fuentes Quintana (dir.), Economía y economistas españoles, vol. 3: La ilustración. Barcelona, Círculo de Lectores-Galaxia Gutenberg, 2000, págs. 7-89, pág. 44.

Véanse también las voces correspondientes a Jovellanos y Cabarrús en Luis Perdices de BLAS, y John ReEder, Diccionario de Pensamiento Económico en España (1500-2000), Madrid, Síntesis, 2003.

4 Adam Sмгтн, Investigación sobre la naturaleza y causas de la riqueza de las naciones [1776], vols., Vilassar de Mar (Barcelona), Oikos Tau, 1987, pág. 464. 
hombre. Por todas partes descuajados los bosques, ahuyentadas las fieras, secos los lagos, acanalados los ríos, refrenados los mares, cultivada toda la superficie de la tierra y llena de alquerías y aldeas, y de bellas y magníficas poblaciones, se ofrecen en admirable espectáculo los monumentos de la industria humana y los esfuerzos del interés común para proteger y facilitar el interés individual ${ }^{5}$.

En este sentido, el ejemplo más espectacular del poder del arte y el ingenio humanos sobre la naturaleza es el de Holanda, convertida en «un jardín continuado y lleno de amenidad y abundancia» a costa de remover todo tipo de estorbos, robándole terrenos al océano y construyendo innumerables canales ${ }^{6}$. Lo importante, en cualquier caso, es que el escritor asturiano enfatiza la gran capacidad humana para transformar el entorno, y que en dicha transformación en pos del progreso - la extensión del cultivo y la multiplicación de las comunicaciones - se destacan positivamente todo tipo de intervenciones sobre el medio natural, incluso en aspectos que hoy consideraríamos destructivos. Jovellanos, por tanto, ensalza la idea del hombre como agente de cambio geográfico de primer orden — al mismo nivel que el agua o el viento — capaz de modificar la naturaleza a gran escala, una concepción que es hija del Siglo de las Luces y cuyo principal exponente fue Georges Louis Leclerc, conde de Buffon (1707-1788) ${ }^{7}$, el mayor científico naturalista del siglo XVIII junto a Linneo. Precisamente, la postura de Buffon frente al medio natural guarda una enorme similitud —incluso en el modo de expresión — con la expuesta por Jovellanos en los dos párrafos anteriormente $\operatorname{citados}^{8}$, algo que no debe resultar extraño, pues en realidad fue la postura

5 Gaspar Melchor de JovelLanos, «El informe de ley agraria [1795]», en Escritos económicos, Madrid, Real Academia de Ciencias Morales y Políticas, 2000, págs. 183-359.

6 Ibid., págs. 318-319.

7 Vid., por ejemplo, la siguiente cita: «El estado en que hoy vemos la naturaleza es obra nuestra tanto como suya. Hemos aprendido a moldearla y a modificarla, a ajustarla a nuestras necesidades y deseos. Hemos hecho, cultivado y fertilizado la Tierra; su apariencia, tal como hoy se nos presenta, es así por completo distinta de lo que era antes de la invención de las artes [...]. Es necesario observar la naturaleza en las regiones recién descubiertas, en los países que nunca han estado habitados [por el hombre occidental] para formarse una idea de su primer estado [...]. Finalmente, la entera faz de la Tierra exhibe hoy el sello del poder del hombre que [...] la ha ayudado tan maravillosamente que es con ayuda de nuestras manos como la naturaleza se ha desarrollado en toda su extensión y ha llegado al punto de perfección y magnificencia en que hoy la vemos», conde de Buffon, «De las épocas de la Naturaleza», Supplements a l'Histoire Naturelle, 1774-89, vol. 5, págs. 3-4, citado en Clarens J. GLacken Huellas en la playa de Rodas. Naturaleza y cultura en el pensamiento occidental desde la Antigüedad hasta finales del siglo XVIII [1967], Barcelona, Ediciones del Serbal, 1996, pág. 611.

En relación con todo ello es interesante destacar que los jardines dieciochescos de la Europa continental fueron entendidos como el reflejo del triunfo de la cultura o la civilización sobre la naturaleza salvaje, P. CoATES, Nature: Western Attitudes since Ancient Times, Cambridge, Polity Press, 1998, pág. 117.

8 Así expresa Buffon su actitud hacia la naturaleza: «La naturaleza salvaje es horrible y letal. [...]. Desecad las marismas, haced que las aguas estancadas corran por regatos y canales, despejad los matorrales y los bosques viejos con el fuego o el hierro. En su lugar haced pastizales y campos arables para que el buey abra sus surcos, 
dominante en la segunda mitad del siglo XVIII ${ }^{9}$, manteniendo aún plenamente su vigencia entre los economistas del siglo $\mathrm{XIX}^{10}$.

La naturaleza, por tanto, se ve «hermoseada» por la mano del hombre en la medida en que se la transforma en productiva y se pone en condiciones de rendir. Todos sus elementos deben movilizarse a fin de contribuir a la prosperidad económica general y proporcionar materias para el comercio exterior ${ }^{11}$. Es decir, la visión de Jovellanos es marcadamente productivista: «En los países aplicados e industriosos nada huelga. Los valles, los montes, los cerros y hasta las duras peñas, todo se aprovecha, todo produce y fructifica» ${ }^{12}$. De hecho, en su «Discurso sobre la felicidad del Principado» (1781) el asturiano invita a seguir en todo momento el ejemplo de aquellas naciones «que saben aprovechar hasta las materias más despreciables» ${ }^{13}$. Por eso, no le es grato «ver morir en los montes» excelentes árboles sin obtener las riquezas que la industria y el trabajo podrían sacar de ellos, o contemplar abundantes cursos de agua desaprovechados, sin que se establezcan en su cauce herrerías o manufacturas ${ }^{14}$. Hasta las playas y arenales, tradicionalmente considerados terrenos incultos, debían ponerse en uso, aunque sólo fuera para el plantío de ciertos árboles que sujetaran el terreno.

Por otra parte, como se ha visto, el interés del Jovellanos economista se centra en la naturaleza útil, lejos de meras consideraciones estéticas o de otro

de modo que una nueva naturaleza salga de nuestras manos [...]. ¡Cuán bella es la naturaleza cultivada! ¡Qué brillante es y cuán espléndida y adornada por los cuidados del hombre! [...] El hombre es el más noble producto de la naturaleza; y la naturaleza, entrañable para el hombre, se multiplica bajo sus cuidados de muchas y deseables maneras. Flores, frutos, cereales y especies animales útiles han sido transportadas y difundidas e incrementadas en grandísima medida; especies inútiles han sido eliminadas; la minería ha progresado. Los torrentes han sido contenidos, los ríos dirigidos y controlados. El mar ha sido vencido. La tierra ha sido restaurada y fertilizada. Los prados risueños, los pastos, las viñas, los huertos de las colinas cuyas cimas están coronadas por árboles útiles y bosques jóvenes, las grandes ciudades que se alzan en lugares desiertos, los caminos y las comunicaciones, son algunas manifestaciones de poder y gloria que muestran suficientemente que el hombre, dueño del dominio de la Tierra, ha cambiado ésta y ha renovado toda su superficie», conde de Buffon, «De la Naturaleza. Primera aproximación», Historia Natural, vol. 12, págs. XIII-XV, citado en Clarens J. GLACKEN, op. cit., págs. 609-611.

9 Horacio CaPeL, Filosofía y ciencia en los debates sobre el territorio en la España del siglo XVIII. Cuadernos de Estudios del Siglo XVIII. Oviedo: Universidad de Oviedo, Instituto Feijoo de Estudios del Siglo XVIII, 2. época, núm. 5, 1995 (1997), págs. 59-100, pág. 98.

10 Por ejemplo, en su ensayo póstumo La Naturaleza J. S. Mill se mostrará como un claro defensor de la idea de Civilización entendida como dominio y transformación de la Naturaleza por el hombre, una realidad buscada y creada mediante el uso de su razón (John Stuart Mill, La Naturaleza [1874], Madrid, Alianza, 1998, pág. 42). También en Marx, por ejemplo, podemos encontrar textos ensalzando sin ambages el dominio humano de la naturaleza, vid. Karl Marx, El Capital, t. I [1867], vol. 2, Madrid, Siglo XXI, 1979, pág. 621; vid. asimismo Miguel CuERdo Mir y José Luis Ramos Gorostiza, Economía y Naturaleza. Una historia de las ideas. Madrid, Síntesis, 2000, pág. 77.

11 Gaspar Melchor de Jovellanos, «Discurso dirigido a la Real Sociedad de Amigos del País de Asturias sobre los medios de promover la felicidad de aquel Principado [1781]». En Escritos económicos, Madrid, Real Academia de Ciencias Morales y Políticas, 2000, págs. 363-407, pág. 402.

\footnotetext{
12 Ibid., pág. 381.

$13 \quad$ Ibid., pág. 396.

$14 \quad$ Ibid., págs. 394-395.
} 
tipo. El hombre domina y se enseñorea de la naturaleza — ahuyentando a las fieras, domesticando animales o aclarando bosques - con el único objetivo de «hacerla servir a sus necesidades» ${ }^{15}$. Así, al resultado más palpable de dicho dominio, el desarrollo de la agricultura, lo considera «el primer apoyo de la fuerza y del esplendor de las naciones», siendo no sólo el medio más fácil y seguro de aumentar la población y proporcionarle bienestar, sino también una fuente importante de virtudes y valores, pues la agricultura es la «madre de la inocencia y del honesto trabajo», al tiempo que promete al Estado un pueblo «laborioso», «sencillo y virtuoso» ${ }^{16}$. Por eso, Jovellanos lamenta profundamente la actitud de los grandes propietarios que prefieren «lo agradable a lo útil», anteponiendo «los bosques de caza, las dehesas de potros, los plantíos de árboles de sombra y hermosura, los jardines, los lagos y estanques de pesca, las fuentes y cascadas, y todas las bellezas del lujo rústico» a las «sencillas y útiles labores de la tierra» ${ }^{17}$.

También al Jovellanos viajero del Diario y de las «Cartas a Ponz» $(c .1795)^{18}$ - cuya observación del paisaje es a menudo un punto de partida para expresar opiniones sobre la tenencia de la tierra, los avances agrícolas o las obras públicas - le gusta la naturaleza controlada, «hecha» a medida del hombre, uniendo siempre la idea de fertilidad a la de belleza. En esto coincidirá por completo con los viajeros ilustrados que visitaron la Península, particularmente con los británicos ${ }^{19}$. Nada más agradable a la vista que un paisaje natural bien cultivado y bien poblado. Frente a «los áridos y desnudos campos de Castilla», están las «gratas sensaciones» que transmite el ameno paisaje asturiano, con «caseríos salpicados acá y allá, muy cuidadosamente cultivados y divididos en prados llenos de muchedumbre de ganados» ${ }^{20}$. De ahí que lo deseable sea convertir los incultos despoblados en lugares «de vida, producción, abundancia y alegría», dando establecimiento a colonos, multiplicando los plantíos y reduciendo vastas áreas a cultivo ${ }^{21}$. Porque aunque Jovellanos reconoce en cierto modo la adversidad propia de buena parte de la naturaleza española —alejándose así del mito

\footnotetext{
15 Gaspar Melchor de Jovellanos, «El informe de ley agraria [1795]», op. cit., pág. 304.

16 Ibid., págs. 299, 219.

17 Ibid., pág. 246.

18 Según José Miguel Caso GonzÁLEZ, «Introducción biográfica y crítica», en Gaspar Melchor de JoveLLanos, Obras en prosa, Madrid, Castalia, 1988, págs. 7-70, pág. 475, las cartas estaban ya prácticamente ultimadas hacia 1789, aunque hacia 1794-1795 Jovellanos volvió sobre ellas para cerrar la versión definitiva.

19 Vid. Consol FreIXA, «Imágenes y percepción de la naturaleza en el viajero ilustrado», Scripta Nova [en línea], Barcelona, Universidad de Barcelona, 15 de junio de 1999, núm. 42, págs. 1-16. 〈http://www.ub.es/ geocrit/sn-42.htm>, [12 de septiembre de 2005], ISSN: 1138-9788.

20 Gaspar Melchor de Jovellanos, «Cartas a Ponz [c. 1795]», en Obras en prosa, Madrid, Castalia, 1988, págs. 118-173, págs. 135 y 138. También en el Diario pueden encontrarse múltiples ejemplos como éste. ${ }_{21}$ Ibid., pág. 135.
} 
del laudes hispaniae-, lo que no pone en cuestión en ningún caso es la capacidad humana para transformar el entorno radicalmente superando todo tipo de dificultades, y en concreto las limitaciones impuestas por un clima «ardiente y seco» o por una orografía «desigual y muy desnivelada $»^{22}$.

La actitud de Jovellanos en relación a la explotación de los diversos recursos naturales es abiertamente optimista, y no plantea cautelas respecto a posibles problemas de agotamiento o degradación. En general, el problema básico para Jovellanos respecto a los recursos naturales es simplemente disponer de los medios necesarios para incrementar la producción y eliminar las trabas legales que impiden su adecuado aprovechamiento.

Así, por ejemplo, en relación a la pesca Jovellanos no plantea preocupación alguna respecto a las posibles amenazas para la riqueza pesquera que pudieran derivarse de una eventual sobreexplotación asociada a la utilización de nuevas artes de pesca y al progresivo incremento de las capturas, preocupación que sin embargo sí mostraron otros autores ilustrados como el padre Sarmiento, José Cornide o Antonio Sáñez Reguart, sobre la base de determinadas evidencias e incluso del surgimiento de situaciones de conflicto social ${ }^{23}$. Jovellanos estaba de acuerdo en que la decadencia de la pesca en Asturias, donde había disminuido el número de barcos y pescadores, podía vincularse al servicio de la marina y al pago de la matrícula de pescadores — un mal necesario al que habría que encontrar alternativa-, pero negaba rotundamente que ello pudiera deberse a la falta de recursos pesqueros, porque éstos eran inmutables a largo plazo. Del mismo modo que era un absurdo creer que la tierra envejecía y se hacía estéril con el transcurso del tiempo — decía Jovellanos citando a Columela—, también era erróneo pensar que pudiera haber problemas de «esterilidad en los mares», pues, más allá de situaciones accidentales y pasajeras, «hablando en general las producciones del mar que sirven de alimento a los peces son siempre iguales y por lo mismo debe serlo su multiplicación» ${ }^{24}$. Lo único que debía hacerse era mejorar las técnicas de pesca y el número de efectivos pesqueros, «pues el mar

22 Véanse a este respecto, por ejemplo, las anotaciones del Diario correspondientes al viaje de Madrid a Gijón, en la jornada del 30 de agosto de 1790, Gaspar Melchor de Jovellanos, Diario (cuadernos I a V, hasta 30 de agosto de 1794), Oviedo, Instituto Feijoo de Estudios del Siglo XVIII, 1994, págs. 84-85.

23 Como muestra Luis Urteaga, La tierra esquilmada. Ideas sobre la conservación de la naturaleza en la cultura española del siglo XVIII, Barcelona, Ediciones del Serbal, 1987, págs. 51-103, estos autores fueron conscientes del carácter limitado de los recursos pesqueros, de las complejas relaciones que se establecían entre los organismos marinos y entre éstos y el área geográfica en la que vivían, y de la fragilidad del equilibrio natural ante una eventual sobreexplotación de los recursos. Vid. también J. López Linaje y J.C. Arbex, Pesquerías tradicionales y conflictos ecológicos (1681-1794), Madrid, Ministerio de Agricultura, Pesca y Alimentación, 1991, en relación a situaciones de conflicto «ecológico» relacionadas con la explotación pesquera en el siglo XVIII.

24 Gaspar Melchor de Jovellanos, «Discurso dirigido a la Real Sociedad de Amigos del País de Asturias sobre los medios de promover la felicidad de aquel Principado [1781]», op. cit., págs. 384-386. 
tiene tanta extensión y tantos senos, [y] la variedad de sus pescados es tan prodigiosa», que del incremento de los medios de pesca se seguiría automáticamente el aumento de las capturas y — por tanto- de la riqueza ${ }^{25}$.

En relación al carbón mineral Jovellanos destacaba también su enorme abundancia en Asturias, donde en los territorios carboneros «las minas se hallan a cada paso»y «las encuentra cualquiera que las busca» ${ }^{26}$. Tal abundancia contribuía a que el valor de las minas —o del carbón en el interior de la tierra - fuera prácticamente nulo, mientras que el valor del carbón extraído respondía sólo al coste del trabajo invertido en su extracción, por lo que ningún capitalista estaba interesado en promover la explotación minera como negocio. Aunque esto cambiaría con el tiempo, llegando a tener las minas un valor «acaso muy grande» a medida que fuera escaseando la madera y aumentara la demanda del carbón de piedra ${ }^{27}$, era evidente que el problema básico del momento era la falta de medios para explotar las minas «con economía e inteligencia», usando máquinas y métodos adecuados que permitieran sacar «mucho carbón con poco trabajo». En cualquier caso, resulta significativo que en sus especializados informes de minas Jovellanos nunca se detenga — siquiera de forma pasajera - a discutir alguna de las cuestiones relacionadas con el carácter limitado, de «recurso fondo», del carbón piedra, quizá porque compartía la vieja idea — vigente aún durante el siglo XVIII — de que los minerales crecían y se perfeccionaban en el seno de la tierra ${ }^{28}$, o simplemente porque su genuino optimismo en relación a la naturaleza y sus disponibilidades dejaba totalmente fuera de lugar tales cuestiones.

\footnotetext{
25 Ibid., pág. 391.

26 Las citas corresponden respectivamente a dos informes de Jovellanos de 1794 y 1793 recogidos por Sebastián CoLL, op. cit., págs. 89 y 60.

27 En el futuro «menguarán las leñas» y «crecerá el consumo de carbón de piedra», haciéndose necesarios conocimientos, máquinas y auxilios para beneficiar las minas. De este modo, «se abrirá un ancho campo a la inteligencia, a la actividad y a la economía de los explotadores [...]. Esto presentará la esperanza de grandes ganancias, los propietarios [de minas] aspirarán a su participación, y su probabilidad descubrirá y determinará el valor de la propiedad, que será siempre progresivo, como el movimiento de la esperanza» (informe de Jovellanos de 1794 recogido en Sebastián Coll, Jovellanos y la minería asturiana, Oviedo, Cátedra Feijoo-Universidad de Oviedo, Textos y estudios del siglo XVIII, 1984, pág. 90).

28 Vid. J. M. NAREDo, La economía en evolución. Historia y perspectivas de las categorías básicas del pensamiento económico, Madrid, Siglo XXI, 1987, págs. 33-34. El gran naturalista C. Linneo (1707-1778) y su discípulo I. J. Biberg, por ejemplo, compartían la idea del crecimiento de los minerales, que era normal en el siglo XVIII. Y es que, al contrario que en astronomía, mecánica, óptica o matemáticas, en mineralogía y geología aún no se habían desarrollado los nuevos enfoques científicos. Sólo muy a finales de siglo Lavoisier fue acogido en la Península y su Tratado (de 1789) fue adoptado por Jovellanos en su Instituto de Gijón, Jean Sarrailh, La España ilustrada de la segunda mitad del siglo XviII [1957], México, Fondo de Cultura Económica, 1992, pág. 456.

Pero hubo que esperar a principios del siglo XIX para que las enseñanzas de la cristalografía se fusionaran con las de la química moderna dando lugar a una mineralogía científica.
} 
Por último, por lo que respecta al arbolado, en el Setecientos resultaba evidente el carácter estratégico de la madera como recurso económico, al ser combustible, material de construcción — particularmente naval- y materia prima para la elaboración de todo tipo de objetos de uso común (como utillaje agrícola, mobiliario doméstico o medios de transporte), siendo además el bosque un complemento esencial de la economía agraria y un espacio de caza y recreo para la nobleza. Jovellanos, consciente de la necesidad de acrecentar la masa forestal, reconocía los constantes pero infructuosos desvelos del gobierno por desarrollar una amplia política de plantíos, la cual había ido acompañada también de un importante esfuerzo de difusión de la silvicultura a partir de los textos de Duhamel de Monceau. Sin embargo, según el economista asturiano el verdadero problema para la multiplicación del arbolado estaba precisamente en la activa intervención pública, esto es, en las trabas institucionales que se habían establecido so pretexto de fomentarlo. De hecho, las pretendidas medidas de protección del arbolado no habían hecho en realidad más que obstaculizar la iniciativa individual, que a la postre era el auténtico motor de la conservación y expansión de los bosques. En efecto, dado que la madera había llegado a alcanzar «un grado de escasez que en algunas provincias [era] enorme», si se dejaba operar a la libre competencia y al mercado sobre la base del derecho de uso exclusivo de los montes por parte de los particulares, la carestía que acompañaba a dicha escasez sería «el mejor cebo del interés», que animado por la libertad «se [convertiría] al cuidado de los montes» ${ }^{29}$. De nuevo, el punto de partida era una visión optimista sobre la prodigalidad de la naturaleza y su capacidad para auto-regenerarse: «no hay cosa más constante que el que los montes se reproducen naturalmente por sí mismos» ${ }^{30}$, y por consiguiente «al cerramiento de las tierras sucederá naturalmente la multiplicación de los árboles [...] [pues] la naturaleza, siempre propensa a esta producción, se presta fácilmente al arte do quiera que la solicita ${ }^{31}$. En suma, bastaría simplemente con eliminar los privilegios de la Marina, derogar las ordenanzas de montes, desvincular y privatizar los montes comunes, y permitir el cercamiento de las propiedades y la plena libertad de explotación y comercio de la madera, para que se produjese en

29 Gaspar Melchor de Jovellanos, «El informe de ley agraria [1795]», op. cit., pág. 224. Este argumento coincide esencialmente con el que utilizan hoy los partidarios de la llamada ecología de libre mercado, como T. L. Anderson y D. R. Leal, es decir, la estricta definición de derechos de propiedad y el libre funcionamiento del mercado - emisor de señales de escasez_ como el mejor medio para conservar la naturaleza. Sin embargo, en el caso de los bosques es evidente que tal argumento choca, entre otros, con el problema de apropiación incompleta, puesto que no es posible apropiarse privadamente de los múltiples beneficios externos que los bosques generan.

30 Ibid., pág. 223.

31 Ibid., pág. 216. 
gran medida la recuperación de las masas forestales. Pero además, remarcaba Jovellanos, los montes nunca estarían mejor cuidados que cuando, reducidos a propiedad particular, se permitiera su aprovechamiento exclusivo ${ }^{32}$.

\section{Entre la «ciencia útil» al servicio de la felicidad pública y la simple} admiración hacia las «maravillas del mundo natural»

El siglo XVIII fue en Europa el de las grandes colecciones de animales y plantas, los voluminosos libros de historia natural, los ambiciosos viajes geográfico-científicos, y el creciente interés por la botánica y la agronomía (con el surgimiento de jardines botánicos, sociedades de estudio, etc.). La naturaleza se convirtió al mismo tiempo en moda, seña de prestigio social y objeto de análisis. En este contexto, un hombre de tan amplias inquietudes intelectuales como Jovellanos no podía quedarse al margen. Así, entre sus muchas facetas, el asturiano fue un gran aficionado a la ciencia. Esto se observa claramente en su «Discurso sobre la geografía histórica» (1800), pero sobre todo en su «Oración sobre el estudio de las ciencias naturales» (1799). Dirigida a los alumnos de su Real Instituto de Gijón con motivo de iniciarse la enseñanza en la institución de un curso de historia natural, el asturiano demuestra en ella estar perfectamente al tanto del estado de los conocimientos científicos y de lo que había significado la revolución científica del siglo XVII. En un rápido repaso de los principales hitos científicos, y tras reivindicar el método experimental de Bacon frente al escolasticismo aristotélico, cita los logros de Copérnico, Kepler, Newton, Galileo, Huygens, Herschel, Descartes, Leibniz, Torricelli, Franklin y Priestley. Además, se refiere de forma específica a los naturalistas que habían hecho contribuciones importantes al estudio de animales y plantas (Kleint, Adanson, Réaumur, etc.), deteniéndose especialmente en Tournefort y Linneo, que «se atrevieron a formar el inmenso inventario de las riquezas naturales, como si no fuesen inagotables», y en «el inmortal Bufón», quien

subiendo a los primeros días del mundo, resolviendo sus antiguas épocas, ilustrando los cielos y las regiones intermedias, y corriendo con pasos de gigante toda la tierra, coronó aquel glorioso monumento que Plinio había levantado a la naturaleza ${ }^{33}$.

$32 \quad$ Ibid., pág. 226.

33 Gaspar Melchor de JovelLanos, «Oración sobre el estudio de las ciencias naturales [1799]», en Obras en prosa, Madrid, Castalia, 1988, págs. 220-241, pág. 225. La cursiva es mía e intenta destacar, una vez más, el radical optimismo de Jovellanos en relación a la naturaleza. Por otra parte, la posición de Jovellanos era claramente contraria a sistemas especulativos en el estudio de la naturaleza. La descripción y la observación debían ser el punto de partida, Horacio CAPEL, op. cit., pág. 78. 
Del mismo modo, tanto la orientación de una parte importante de su biblioteca ya en $1778^{34}$, como el hecho de haber escrito un Tratado de botánica mallorquina (1801), o algunas citas concretas de su Diario —referidas tanto a lecturas realizadas como a numerosas observaciones naturalistas y meteorológicas-, son también buenas muestras de la enorme atracción que Jovellanos sintió hacia las ciencias a lo largo de toda su vida. Al margen de la botánica, parece que el escritor asturiano estuvo asimismo particularmente familiarizado con la geología y la química. Los informes mineros y el Diario están llenos de observaciones sobre masas rocosas, vetas minerales o fenómenos geológicos de todo tipo que demuestran unos sólidos conocimientos en la materia ${ }^{35}$. Además, parece que el propio Jovellanos llegó también a practicar en mayor o menor grado, aunque fuera de forma elemental, el análisis químico-mineral con objeto de estudiar la calidad de distintos tipos de carbón o la composición de ciertos minerales ${ }^{36}$.

Pero todo ese inusitado interés científico no era abstracto, puramente especulativo o gratuito. Como queda patente de forma especial en el «Elogio a Carlos III» (1789), estaba dirigido esencialmente hacia una «ciencia útil», orientada a la práctica para mejor contribuir así a la «felicidad de los Estados», esto es, se trataba de promover una ciencia aplicada al servicio del progreso socioeconómico y la prosperidad nacional ${ }^{37}$. La mejor prueba en este sentido fue, sin duda, la ya aludida creación por Jovellanos, en 1794, del Real Instituto de Náutica y Mineralogía, «para enseñar ciencias exactas y naturales,

34 Según recoge Francisco AgUILAR PIÑal, La biblioteca de Jovellanos (1778), Madrid, Instituto Miguel de Cervantes-CSIC, 1984, págs. 129-142, en la biblioteca de Jovellanos había textos de historia natural e historia de las ciencias, tratados médicos, libros de matemáticas, trabajos sobre prácticas agrícolas, y textos generales de filosofía natural. Pero además, como señala Jean Pierre CLÉMENT, Las lecturas de Jovellanos (ensayo de reconstrucción de su biblioteca), Oviedo, Instituto de Estudios Asturianos, 1980, págs. 7-8, hay que tener en cuenta que se trata aún sólo de la biblioteca de 1778: como lo atestigua el Diario, será precisamente durante los diez años que pasará en Gijón, de 1790 a 1800, cuando Jovellanos se entregue más intensamente a la lectura para impulsar su Real Instituto Asturiano, con una importante presencia de obras de carácter práctico y técnico-científico.

35 Vid. como botón de muestra las detalladas observaciones geológicas que anota Jovellanos en su Diario en un viaje a Pajares en la jornada del 18 de noviembre de 1793, Gaspar Melchor de JoveLLAnos, Diario (cuadernos I a V, hasta 30 de agosto de 1794), Oviedo, Instituto Feijoo de Estudios del Siglo XVIII, 1994, págs. 486-487.

36 Vid. en este sentido las explícitas citas de Jovellanos que recoge y discute Joaquín Mulas SÁnchEz, «Jovellanos y la Naturaleza», en Memoria del Curso 1961-1962, Real Instituto Jovellanos de Enseñanza Media, Gijón, 1963, págs. 90-105, págs. 95-96, procedentes de su correspondencia y su Diario. Como comenta este autor, es muy probable que — por ejemplo— el análisis de la calidad del carbón no pasase del reconocimiento elemental que consiste en quemar un peso determinado de carbón y luego pesar las cenizas residuales, para deducir con éstos dos valores la cantidad relativa de carbono que poseía el mineral. Con todo, ello ya indica una formación técnica notable para la época.

37 Gaspar Melchor de Jovellanos, «Elogio de Carlos Tercero [1789]», op. cit., pág. 490. Vid. también, por ejemplo, Gaspar Melchor de Jovellanos, «Cartas a Ponz [c. 1795]», en Obras en prosa, Madrid, Castalia, 1988, págs. 118-173, pág. 222. 
criar diestros pilotos y hábiles mineros, [y] sacar del seno de los montes el carbón mineral», según se leía en la inscripción de los transparentes de ocho ventanas del edificio. En la parte superior del escudo de la institución, además, rezaba una inscripción muy reveladora: «A la Verdad y a la Utilidad Pública» ${ }^{38}$. $Y$ es que, tal como ha subrayado Llombart ${ }^{39}$, junto a una curiosidad insaciable y enciclopédica hacia la naturaleza, las ciencias y las artes, el otro rasgo esencial de la biografía de Jovellanos fue su marcado pragmatismo reformador, siempre a la búsqueda de las ideas de mayor utilidad social. Él mismo dio múltiples muestras de su espíritu práctico, y así, por ejemplo, en su Diario queda bien reflejado un notable conocimiento — entre otras cosas — de las técnicas agrí$\operatorname{colas}^{40}$.

La visión de la naturaleza que deriva de este interés científico expresado en términos de «ciencia útil» es otra vez la de la naturaleza como territorio para la acción humana. Como en el caso del Jovellanos economista, para quien —como se vio anteriormente - la naturaleza es básicamente una fuente de estorbos físicos a vencer en aras del progreso, el Jovellanos aficionado a las ciencias naturales, en principio, también parece aproximarse a la naturaleza del mismo modo: el hombre debe servirse de las «ciencias útiles» —entre las que se cuenta la economía política ${ }^{41}$ — para controlar y dominar activamente el medio que le rodea y promover de esta forma la prosperidad general. Así, el ser humano, «capaz de comprender a un mismo tiempo la extensión de la tierra, la profundidad de los mares y la altura e inmensidad de los cielos, [así como][...] de penetrar los más escondidos misterios de la naturaleza», sólo necesita reunir, combinar y ordenar sus ideas «para sujetar el universo a su dominio» y «la felicidad a su albedrío» ${ }^{42}$. El planeta «se le rinde», y es capaz de «remover sus montes, levantar sus ríos [y]

38 Jean SARRallh, op. cit., pág. 174.

39 Vicent Llombart, «Estudio introductorio», en Gaspar Melchor de Jovellanos, op. cit., pág. 19.

40 Hay referencias muy específicas en el Diario que demuestran el conocimiento propio de un técnico. Por ejemplo, en el diario primero de 1790 hay una amplísima y detallada descripción de las labores relacionadas con el cultivo del maíz en su época, Gaspar Melchor de Jovellanos, Diarios, Madrid, Alianza, edición de Julián Marías, 1967, págs. 29-32. También se encuentran referencias concretas a la realización de plantíos y al aprovechamiento de maderas, por ejemplo en el diario segundo de 1791 (itinerario VI, día 12), al describir la recogida de leñas para los carbones de La Cavada, Gaspar Melchor de Jovellanos, Diarios, op. cit., págs. 33-34. Pero además, como viajero ilustrado, Jovellanos no sólo examina a su paso los ingenios mecánicos o las tareas agrícolas, sino que se interesa por cuestiones tales como las posibilidades técnicas de realización de obras públicas (caminos, puertos, canales, etc.) o la condición económica general de las zonas que visita.

${ }^{41}$ Para Jovellanos, la economía política era necesaria para hacer provechosa la aplicación útil de las otras ciencias (mineralogía, metalurgia, historia natural, botánica, química, etc.). En el «Elogio a Carlos III» dice: «Su fin es apoderarse de estos conocimientos, distribuirlos útilmente, acercarlos a los objetos de provecho común, y en una palabra, aplicarlos por principios ciertos y constantes al gobierno», Gaspar Melchor de Jovellanos, «Elogio de Carlos Tercero [1789]», en op. cit., pág. 488.

$42 \quad$ Ibid., págs. 487-488. 
atravesar sus golfos» porque su mano es «instrumento admirable de invención, de ejecución [y] de perfección capaz de mejorar la naturaleza, de dirigir sus fuerzas, de aumentar y variar y transformar sus producciones, y de someterlas a sus deseos» sobre la base de la razón ${ }^{43}$.

Sin embargo, junto a este nuevo canto al poder humano, a la capacidad del hombre para transformar activa y hondamente el entorno geográfico-natural en su propio provecho, hay también en los textos del Jovellanos aficionado a las ciencias una fuerte presencia de la idea providencialista de la naturaleza, de donde deriva esencialmente una visión del hombre como espectador pasivo en actitud de sencilla admiración y respeto frente a las maravillas realizadas por el Creador ${ }^{44}$. Así, tras subrayar «las admirables relaciones que nos enlazan con nuestro globo», Jovellanos exclama: «¡Oh, cómo resplandece sobre [la Tierra] la beneficencia de Dios! Doquiera que volváis los ojos hallaréis impresa la marca de su omnipotencia y su bondad!». El escritor asturiano siente asombro ante la enorme diversidad de los distintos reinos naturales, ensalza la gran cadena del ser y se sorprende frente a las prodigiosas fuerzas creadoras y destructoras de la naturaleza. Ésta es, en definitiva, el fiel reflejo de Dios, como muestra «la conveniencia, la armonía, y el orden patente y magnífico que brilla por todas partes». Es decir, la naturaleza responde a un plan divino que garantiza en cualquier caso su «inmutable conservación» al margen de las posibles acciones humanas, idea que se encuadra en una concepción estática y optimista de la naturaleza que lleva aparejada la despreocupación ante posibles efectos negativos asociados al disfrute de los recursos naturales, y que además tiene tintes teleológicos e incluso resabios organicistas ${ }^{45}$.

43 Gaspar Melchor de Jovellanos, «Oración sobre el estudio de las ciencias naturales [1799]», op. cit., págs. 239.

44 El marcado providencialismo de Jovellanos ha sido también subrayado por Horacio CAPEL, op. cit., págs. 64-65.

45 Así, por ejemplo, en la descripción que hace Jovellanos del sistema celeste parece que todo estuviera dotado de una vida animada, vid. Gaspar Melchor de Jovellanos, «Oración sobre el estudio de las ciencias naturales [1799]», op. cit., págs. 226-227. Y es que aunque la concepción mecanicista del mundo se fue abriendo camino paulatinamente desde la revolución científica del siglo XVII, la visión organicista había tenido tal arraigo que aún dejó notar su influencia, aunque sólo fuera en el lenguaje, durante mucho tiempo después. Además, en España hubo una reacción antimecanicista importante en el círculo mayansiano, de la mano de Andrés Piquer, Francisco Sánchez-Blanco, La mentalidad ilustrada, Madrid, Taurus, 1999, págs. 225-239. Por otro lado, parece que en Gaspar Melchor de JovelLanos, «Oración sobre el estudio de las ciencias naturales [1799]», en op. cit., págs. 227-228, aún pervivía también de alguna manera la vieja teoría de los cuatro elementos. Es cierto que con el desarrollo de las ciencias naturales dicha teoría se fue progresivamente desvalorizando hasta ser expulsada definitivamente del ámbito científico. Así, en el ámbito de la física se había desvalorizado por completo hacia finales del siglo XVII. Sin embargo, durante el siglo XVIII — dado el tardío desarrollo de la química moderna- la teoría de los cuatro elementos continuó teniendo mayor o menor validez, Gernot y Harmut Böнme, Fuego, agua, tierra, aire: una historia de la cultura de los elementos, Barcelona, Herder, 1998, pág. 157. 
El fin último de todo lo que existe en el mundo físico-natural, su causa final, es servir al hombre, el «rey de la Tierra» situado en el «centro de todas las relaciones que presenta la armonía del universo». Así, el ser de utilidad al hombre, a sus actividades económicas, es el destino último de las intrincadas interconexiones y balances que hay en la naturaleza, donde «todo está enlazado» y «ordenado hacia el gran fin»:

Sin los despojos de los árboles y los vivientes, sin las aguas que fluyen de las alturas, fueran estériles los valles, y no nacieran el rubio grano ni la brizna de hierba, ni el trabajo del hombre recogería tanta abundancia de bienes que la industria mejora y multiplica, el comercio cambia, y la navegación difunde ${ }^{46}$.

La idea del hombre como agente de cambio geográfico (que, como se ha visto, domina los textos del Jovellanos economista y también está presente en gran medida en los del aficionado a las ciencias) no es incompatible con la vieja idea de designio o la visión providencialista de la naturaleza (que, tal como se acaba de mostrar, tiene tanto peso en la «Oración sobre el estudio de las ciencias naturales» o en el «Discurso sobre la geografía histórica»): el hombre colabora a través de sus actos a perfeccionar la gran obra de la Creación. Es decir, la Tierra, creada por Dios, ha sido dispuesta armoniosamente para cubrir las necesidades del hombre, que ocupa la cúspide de la jerarquía de la vida, al tiempo que éste cumple la misión de completar la creación y poner orden en la naturaleza tal como Dios lo había planeado ${ }^{47}$. Como señala el propio Jovellanos ${ }^{48}$, la naturaleza reúne siempre «grandeza y utilidad», y por tanto se dan la mano Providencia y Razón, conviviendo la actitud de veneración ante lo creado junto a la de explotación y transformación activa de la naturaleza como recurso ${ }^{49}$ :

46 Gaspar Melchor de Jovellanos, «Oración sobre el estudio de las ciencias naturales [1799]», op. cit., págs. 237-238.

47 Clarence J. Glacken, op. cit., pág. 28.

48 Gaspar Melchor de JovelLanos, «Oración sobre el estudio de las ciencias naturales [1799]», op. cit., pág. 230.

49 Linneo, cuya obra demuestra conocer Jovellanos, es quizá el máximo representante del maridaje entre Providencia y Razón que acaba de reseñarse. Su sistema de clasificación de las especies es una clara muestra de la búsqueda de un orden racional — de una pauta subyacente — en la desconcertante variedad del mundo viviente, partiendo del supuesto de que las especies eran eternamente fijas y habían sido determinadas desde un principio según un plan divino. Pero al mismo tiempo que expresa su veneración por la enorme diversidad natural obra de Dios, la naturaleza es interpretada por Linneo en términos esencialmente prácticos, como un sistema o mecanismo planeado para que la humanidad lo explote. Como señala Peter J. Bowler, Historia Fontana de las ciencias ambientales, México, FCE, 1998, pág. 124, «el mismo término "economía" [de la naturaleza] implica que el sistema ha sido ordenado para el beneficio material de alguien. [...] Dios había creado la economía del mundo para sostener a la humanidad, y lo hacía feliz vernos modificar el sistema si lo juzgábamos conveniente [...]. El hecho de que hubiera tantas especies útiles para los humanos sugería que el 
¿Qué sería de la naturaleza toda si, muda y solitaria no oyese la voz ni sintiese la mano del hombre encargado de educarla y dirigirla? ¿No es él solo a quien el benigno Creador dio a conocer sus fuerzas y a aumentar y difundir sus dones y gracias? [...] La continua industria [del hombre] pone el colmo a tantas bellezas ${ }^{50}$.

Sin embargo, lo cierto es que la idea del designio — que hundía sus raíces en el pensamiento griego-medieval y que aún daría mucho que hablar en el debate evolucionista del siglo XIX ${ }^{51}$ — había recibido ya en la segunda mitad del siglo XVIII críticas de gran calado por parte de autores tan importantes como Buffon, Hume, Goethe, Voltaire, Kant o el barón de Holbach, entre otros ${ }^{52}$. Es improbable que Jovellanos desconociera por completo tales críticas, pues sabemos con seguridad que al menos estaba al tanto de la obra de Buffon y Voltaire. Además, el gran terremoto de Lisboa de 1755, que también afectó a algunas ciudades del sur de la Península, suscitó en España - como en otros países de Europa - serias dudas respecto a la bondad y armonía de la Creación y la interpretación providencialista del mundo ${ }^{53}$. Por tanto, se pueden considerar dos posibilidades.

Lo más probable es que, a pesar de todo, Jovellanos creyera firmemente en la físicoteología, situándose así en la misma línea que autores como Linneo y Herder (o anteriormente Leibniz, Ray y Derham), y dando continuidad a una

Creador deseaba que nosotros nos hiciéramos cargo de la máquina y la manipuláramos en beneficio nuestro». Por supuesto, para Linneo era inimaginable que la interferencia humana pudiera alterar el equilibrio de la naturaleza —definido por las cadenas alimenticias—. Dicho equilibrio entre las especies era estable por mandato divino pero flexible, permitiendo que pudieran multiplicarse poblaciones de ciertas especies valiosas para los seres humanos y destruir las plagas.

50 Gaspar Melchor de Jovellanos, «Descripción del Castillo de Bellver [1806]», en Obras en prosa, Madrid, Castalia, 1988, págs. 275-345, pág. 314.

51 La Teología Natural (1802) de William Paley fue una obra fundamental en la juventud de Darwin. El libro, que seguía girando en torno a la idea básica de que la naturaleza revela en todos sus aspectos un plan coherente que constituye la prueba innegable de la existencia del supremo planificador, era conocido por todas las personas cultas en Gran Bretaña y era de estudio obligatorio para los universitarios. En la década de 1830 de nuevo se reexpuso con fuerza la misma doctrina en los ocho «Tratados Bridgewater», escritos por respetados científicos, S. Gordon, Historia y filosofía de las ciencias sociales, Barcelona, Ariel, 1995, pág. 551.

52 Para una amplia discusión de las críticas al providencialismo vid. Clarence J. GLAcKen, op. cit., págs. 479-496. Las críticas, en concreto, iban esencialmente dirigidas a la idea de causa final en la naturaleza, a la idea de orden y perfecta armonía en la Tierra, y a la analogía del gran artesano creador. Entre los naturalistas, Buffon fue quien, desde un claro materialismo, defendió con más fuerza que la estructura existente de la Tierra y sus habitantes eran producto de procesos naturales y no creación divina: la naturaleza tenía en sí misma poderes creadores a través de la llamada «generación espontánea», Peter J. Bowler, op. cit., págs. 134-136. Asimismo, Buffon es también un claro representante del «vitalismo» — la creencia de que la vida es una fuerza distinta que no puede explicarse en términos puramente mecanicistas—, que empezó a cobrar fuerza a mediados del siglo XVIII dentro de las ciencias de la vida, vid. Peter Hanns ReIL, Vitalizing Nature in the Enlightenment, Berkeley y Los Angeles, University of California Press, 2005.

${ }^{53}$ Francisco Sánchez-Blanco, op. cit., págs. 243-275. 
postura que tenía una larga tradición en la cultura española ${ }^{54}$. En este sentido, es significativo que ya en 1778 uno de los libros destacados de la biblioteca de Jovellanos fuera la Contemplación de la Naturaleza (1770) de Charles Bonnet, uno de los principales defensores en el siglo XVIII de la imagen de la naturaleza como sistema creado por la Divinidad ${ }^{55}$. Por otro lado, sin embargo, es posible también que la reiterativa insistencia de Jovellanos en la idea providencialista de la naturaleza respondiera, más que a una genuina convicción sin fisuras, al deseo de evitar problemas con la Inquisición, siempre recelosa ante cualquier discusión de ideas científicas que pudiera poner en duda los principios de la teología natural ${ }^{56}$. En este sentido, no hay que olvidar que la obra de Buffon, que Jovellanos demuestra conocer y que fue el autor que mayores esfuerzos hizo por impugnar la historia bíblica de la creación divina, se hizo popular en España a partir de la década de $1780^{57}$. Además, algunas de las cosas que Buffon había enfatizado en su obra y que Jovellanos recoge en sus escritos — como la existencia de fósiles (en sus Diarios) o la idea de la «gran cadena del ser» (en su «Oración») — cuadraban difícilmente con las enseñanzas de las Sagradas Escrituras $^{58}$. Con todo, hay que admitir que se trata de aspectos apuntados sólo

54 Vid. Francisco Garrote, La naturaleza en el pensamiento de Cervantes, Salamanca, Ediciones Universidad de Salamanca, 1979, págs. 13-28, en referencia a la concepción providencialista en el Renacimiento y en el Barroco español. En el siglo XVIII el principal representante en España de la visión providencialista de la naturaleza fue el jesuita ilustrado Juan Francisco Masdeu (1744-1817), Luis UrTEAGA, op. cit., pág. 23.

55 Bonnet se situaba en la línea del célebre Espectáculo de la Naturaleza (1732-1750) del abate Nöel Pluche, donde se planteaba la idea de designio de forma extrema y bastante ingenua. Esta obra de historia natural en quince tomos, en la que la idea de causa final ocupaba un lugar central a la hora de explicar la conformación del entorno físico, rivalizó en popularidad con la obra de Buffon en Francia en el siglo XVIII, y sobre todo tuvo una enorme difusión en España a través de su traducción en 1753 y sus tres ediciones posteriores (la última de 1785). Es muy probable, por tanto, que Jovellanos conociera también bien la obra de Pluche, Jean SARraiLH, op. cit., pág. 457.

56 Como ha destacado Capel, Horacio CaPel, op. cit., pág. 87, para defender la ciencia y el estudio de la naturaleza Jovellanos no duda en utilizar argumentos religiosos en su «Oración» de 1799: el Creador expone la naturaleza a la contemplación del hombre para que vea en ella su poder y su gloria.

57 En 1785 Clavijo y Fajardo comenzó a publicar en español la monumental obra de Buffon, su Historia Natural en treinta y seis volúmenes (1749-1788). Pero desde principios de la década de 1770 los escritos de Buffon empezaron ya a ser conocidos entre la élite intelectual española, circulando entre los naturalistas aficionados, Jean Sarrailh, op. cit., pág. 462. Dichos escritos fueron vistos siempre con prevención desde las instancias eclesiásticas. Así, por ejemplo, Buffon fue juzgado por la Iglesia católica por sus afirmaciones sobre la edad de la Tierra (que calculaba muy superior a los 6.000 años proclamados por la doctrina oficial), y finalmente hubo de retractarse.

$58 \quad$ Frente a la idea del fijismo de las especies y de estabilidad en la configuración terrestre de acuerdo a un plan predeterminado por Dios, los fósiles remitían a una noción de cambio y dinamismo tanto en la naturaleza — la posibilidad de extinciones — como en la corteza terrestre — ante la aparición, por ejemplo, de fósiles marinos en zonas de montaña- Por su parte, frente a la interpretación tradicional cristiana que hacía del hombre un ser aparte, hecho a imagen de Dios, la concepción de la "gran cadena del ser" transmitía la idea de plenitud y continuidad en la naturaleza, con la existencia de todas las formas de vida concebibles en una misma línea vertical y sin una división nítida entre los minerales y los seres vivos más simples, María del 
de pasada por el escritor asturiano, cuyas implicaciones últimas no analiza. Lo mismo ocurre con otra gran idea filosófico-geográfica vigente en el siglo XVIII, la de la influencia del medio natural en la civilización, que tan radicalmente defendiera Montesquieu en El espíritu de las leyes y que aparece en la obra Jovellanos de un modo absolutamente fugaz ${ }^{59}$.

\section{Ecos rousseaunianos y sensibilidad prerromántica: la exaltación de la belleza y de los valores de la naturaleza}

La actitud conservacionista hacia la naturaleza que se ha impuesto en el mundo occidental desde finales del siglo Xx —en concreto la valorización de sus aspectos más salvajes y la exaltación de los sistemas naturales amenazados- tiene una de sus principales raíces en el Romanticismo ${ }^{60}$. Pues bien, en España Jovellanos fue uno de los autores que introdujeron el nuevo sentimiento de la naturaleza que luego se asociaría a la sensibilidad romántica. Lejos del pintoresquismo dieciochesco que simplemente se fijaba en una imagen peculiar con cualidades plásticas ${ }^{61}$, o del mero bucolismo que evocaba de modo idealizado la vida campestre, el autor asturiano empezó a expresar la idea de comunión con la naturaleza que tan singularmente acabaría caracterizando al romanticismo.

En sus poesías — la epístola cuarta «de Fabio a Anfriso» y la quinta «a Batilo» - aparece ya la idea de disfrute asociado a la experiencia y contemplación de la naturaleza y a una nueva valoración de lo silvestre ${ }^{62}$. Frente al «bullicio

Carmen Iglesias, El pensamiento de Montesquieu: política y ciencia natural, Madrid, Alianza, 1984, pág. 191. Otro reto a la concepción providencialista de la naturaleza era explicar la «extraña» distribución de la fauna y la flora que poblaban continentes e islas remotas y cuya arribada a los mismos planteaba serias dudas, Luis URTEAGA, op. cit., pág. 16. A pesar de todo, la mayor parte de los naturalistas, como el propio Linneo, siguieron buscando la adaptación de sus teorías a la idea de designio y al relato bíblico (p. ej., al diluvio universal). Así nacieron, por ejemplo, la teoría del océano en retroceso, la noción de las regiones botánicas y zoológicas (que postulaba varios centros de creación divina), o la teoría de la multiplicación de las especies sin evolución (por la que, dentro de su plan, Dios había creado una especie de cada género y luego las demás habían surgido por hibridación entre las formas originales), J. BowLER, op. cit., págs. 102-131.

59 El asturiano afirma que sin el conocimiento de la geografía física no podrían organizarse las sociedades ni regularse su gobierno, pues «ella es la que fija sus límites y los subdivide, la que determina los objetos de las leyes y su conveniencia, y la que señala la necesidad y el provecho de sus instituciones», Gaspar Melchor de Jovellanos, «Cartas a Ponz [c. 1795]», en Obras en prosa, Madrid, Castalia, 1988d, págs. 118-173, pág. 246.

60 Peter Coates, op. cit., pág. 125.

61 Como señala Peter Contes, op. cit., pág. 32, el término «pintoresco» se tomó del arte del paisajismo y se refería a una escena potencialmente «enmarcable». En último término trataba de adaptar la descripción de la belleza natural a los principios del paisaje «artificial».

${ }^{62}$ A veces se ha situado estos trabajos poéticos de Jovellanos dentro del mero bucolismo, pero ya hay en ellos elementos que lo trascienden. En las poesías de Meléndez Valdés (a quien Jovellanos llamaba 
de las altas ciudades» y al «mundanal tumulto» de la ambición y el lujo, donde sólo aguardan «sinrazones, vanos deseos, duros desengaños, susto y dolor» que «turban nuestro pecho», la naturaleza es para Jovellanos ${ }^{63}$ una fuente inagotable de consuelo y reposo espiritual: «dulce soledad y alto silencio», paz y alegría. Así, enfrenta la civilización urbana a la naturaleza salvaje y a las «arduas cumbres», y antes que las bellezas del arte derivadas del ingenio humano prefiere las genuinas bellezas naturales que son siempre «su fuente y santo prototipo». Es más, si uno «observa reflexivo los milagros de la naturaleza» podrá verse «unido a Dios por medio de la santa contemplación». El paisaje llega incluso a tener un carácter simbólico, como expresión patriótica. Así, en la epístola a Batilo, la visión de los Picos de Europa, «venerable antemural», lleva a Jovellanos a rememorar las glorias de la Reconquista.

Todos estos aspectos que aparecen ya claramente apuntados en las poesías se desarrollan luego en muchos de sus escritos en prosa. En las «Cartas a Ponz», por ejemplo, pueden encontrarse algunas claras muestras de sensibilidad romántica. Jovellanos expresa una admiración sin límites por las «maravillas de la creación» en su estado salvaje ${ }^{64}$, y destaca a menudo el carácter sublime del espectáculo natural, especialmente cuando uno se encuentra ante la grandiosidad de la naturaleza y su inmensidad solitaria y sobrecogedora, que genera un disfrute estético y posee un gran valor espiritual. Así, por ejemplo, en el paso de Puente Tuero, camino a Oviedo, dice:

¡Si viera usted qué sublimes son por su forma y su altura las dos enormes rocas de cuarzo, escarpadas perpendicularmente! [...] Aquellas elevadísimas rocas, [...] ofrecen a la vista un espectáculo grande, raro y en cierto modo magnífico, llenan el espíritu de ideas sublimes y profundas, le ensanchan, le engrandecen y le arrebatan a la contemplación de las maravillas de la creación ${ }^{65}$.

Batilo) el bucolismo sí es más claro: la exaltación de la naturaleza aparece vinculada al tema del buen salvaje y la primera edad de oro, donde se contrapone el bárbaro-bondadoso, que vive en armonía con su medio, al civilizado-corrompido, José Luis abellán, Historia crítica del pensamiento español, 3. Del Barroco a la Ilustración, Madrid, Espasa Calpe, 1981, pág. 634. Anticipa de algún modo la visión de la naturaleza como Arcadia perdida y añorada, fuente de paz y belleza.

63 Gaspar Melchor de Jovellanos, Poesías [libro en línea], Alicante, Biblioteca Virtual Miguel de Cervantes, 2003, 〈www.cervantesvirtual.com/FichaObra.html?Ref=4007〉, [25 de septiembre de 2005].

64 «Los grandes objetos que la naturaleza reunió en su suelo. ¿Pudo usted observar sin admiración en su viaje sus frondosos bosques, sus valles amenísimos, sus montes levantados hasta las nubes, sus ríos, ya precipitados de lo alto de las cumbres por extrañas y vistosas cascadas, o ya brotando de repente al pie de su falda? ¿Pudo usted dejar de sorprenderse agradablemente a la vista de tantas eminencias, precipicios, alturas, cañadas, grutas, fuentes minerales, lagos, ríos, puertos, playas y en fin, cuanto produce de grande y singular la naturaleza?», Gaspar Melchor de Jovellanos, «Cartas a Ponz [c. 1795]», op. cit., págs. 133-134.

65 Gaspar Melchor de Jovellanos, «Cartas a Ponz [c. 1795]», op. cit., pág. 137. 
Jovellanos aprecia particularmente el vigor, la plenitud y la sublimidad del paisaje de montaña, que luego será tan revalorizado por el romanticismo unido a las fuertes emociones que suscita la visión de altas cumbres, escarpados precipicios rocosos o torrentes tumultuosos. En sus Diarios aparecen múltiples ejemplos en este sentido:

Estrechísima garganta [...] Arriba tajo altísimo, horridísimo (sic), pero magnífico y sublime cuanto puede presentar la naturaleza [...]. Por esta bella carretera [...] se va un gran trecho con la peña sobre el sombrero, el río bajo los pies, la sorpresa bajo la imaginación y el susto en el pecho ${ }^{66}$.

Pero la naturaleza es tan admirable en lo grande e insólito como en lo pequeño y cotidiano, y el asombro llega también ante la contemplación de una simple tela de araña, que elabora su portentosa tela sin instrumento alguno ${ }^{67}$.

Jovellanos no se cansa de exaltar una y otra vez la hermosura natural, que le conmueve profundamente, reivindicando con insistencia el goce estético y espiritual que proporciona: « Hombre!, si quieres ser venturoso contempla la Naturaleza y acércate a ella; en ella está la fuente del escaso placer y felicidad que fueron dados a tu ser...» ${ }^{68}$. A su vez, la inmensidad inabarcable de los esce-

66 Gaspar Melchor de Jovellanos, Diarios, Madrid, Alianza, edición de Julián Marías, 1967, pág. 76, diario cuarto 1792, itinerario VII, viernes 20 de julio. En términos similares se expresa también en otras muchas ocasiones. Por ejemplo: «De Pajares a Posadorio [...] es inmenso el desnivel [...]. Pero todo es bello a una y otra parte, todo sublime, todo grande», ibid., pág. 83, diario quinto 1793-1795, itinerario IX, lunes 18 de noviembre de 1793. Otra muestra: «Donde la naturaleza es tan grande y vigorosa, todo contribuye a aumentar la sublimidad de las escenas. El sol es aquí más brillante, los vientos más recios e impetuosos, las mudanzas del tiempo más súbitas, las lluvias más gruesas y abundantes, más penetrantes los hielos, y todo participa de la misma grandeza», ibid., págs. 81-82, diario quinto 1793-1795, itinerario IX, domingo 17 de noviembre de 1793.

67 «Telas de araña hermoseadas por el rocío [...]. Cada gota un brillante, redondo, igual, de vista muy encantadora. Marañas entre las árgomas, no tejidas vertical, sino horizontalmente, muy enredadas, sin plan ni dibujo. ¡Cosa admirable! Hilos que atraviesan de un árbol a otro a gran distancia, que suben del suelo a las ramas sin tocar el tronco, que atraviesan un callejón. ¿Por dónde pasaron estas hilanderas y tejedoras, que sin rama ni urdimbre, sin lanzadera, peine ni enxullo tejen tan admirables obras? ¿Y cómo no las abate el rocío? El peso del agua que hay sobre ellas excede sin duda en un décuplo al de los hilos. Todo se trabaja en una noche; el sol del siguiente día deshace las obras y obliga a renovar la tarea», ibid., pág. 27, diario primero 1790, itinerario III, 27 de septiembre.

68 Jovellanos, ibid., pág. 120, diario quinto 1793-1795, miércoles 30 de julio de 1794. Otras tantas exclamaciones en términos parecidos están desperdigadas por los Diarios. Por ejemplo: «iOh naturaleza! ¿Qué desdichados son los que no pueden disfrutarte en estas augustísimas escenas, donde despliegas tan magníficamente tus bellezas y ostentas toda tu majestad!», ibid., pág. 73, diario tercero 1792, itinerario VII, jueves 28. O por ejemplo esta otra: «En torno, altos y ojosos negrillos y mucha frondosidad; era el crepúsculo de la tarde; el cielo claro y sereno; la luna nueva brillaba dulcemente en lo alto; el canto de los ruiseñores, el ruido del agua, la sombra de los altos árboles... ¡Oh naturaleza! ¡Oh deliciosa vida rústica! ¡Y que haya locos que prefieran otros espectáculos a éstos, cuya sublime magnificencia está preparada por la sabia y generosa mano de la naturaleza!», ibid., pág. 167, diario sexto 1795-1796, itinerario X, jueves 21 de mayo de 1795. 
narios naturales, frente a la que el ser humano se siente infinitamente pequeño e insignificante, le lleva a reflexionar sobre la inconmensurable grandeza del Dios creador. A veces parece incluso apuntar implícitamente que el hombre, humilde espectador de esa naturaleza que integra el ciclo de las horas del día y las estaciones, del devenir y el perecer, también forma parte en última instancia del «cuadro» que contempla. Es decir, el hombre es parte de la naturaleza y no un ser al margen de ella destinado a someterla a su antojo como dictaba la tradición judeo-cristiana ${ }^{69}$. Además, la naturaleza, en su grandiosidad, tiene algo de misterioso e incompresible que la razón humana no podrá llegar nunca a desentrañar ${ }^{70}$.

El paisaje que describe el Jovellanos prerromántico es en realidad una expresión de estados de ánimo, una creación de su subjetividad o de su «visión interior». Esto se deja notar en algunas reseñas en los Diarios ${ }^{71}$, pero es especialmente evidente en la «Descripción del Castillo de Bellver» (1806), donde todo lo que observa en relación al paisaje que rodea al castillo lo transmite expresando soledad, tristeza y abandono. En palabras de Caso González ${ }^{72}$, se trata de «un paisaje real que a Jovellanos le emociona y a través del cual el sentimiento expresa toda la dolorida carga del hombre injustamente perseguido y desamparado». Es cierto que en la «Descripción» vuelve a aparecer el Jovellanos aficionado a las ciencias naturales y el economista: enumera con detalle la gran diversidad de especies animales y vegetales que rodean al castillo ${ }^{73}$, se refiere a fósiles de conchas y mariscos situados en una zona que en su día debió estar cubierta por el mar $^{74}$, y también aprovecha para hablar de los suelos ${ }^{75}$, de la situación geográfica,

69 En el cristianismo y el judaísmo (y también en el Islam) está claramente presente la idea de dominio humano sobre el medio natural, mientras que en las religiones orientales (budismo, taoísmo, hinduismo, etc.) ha primado más bien la «identificación» del hombre con su entorno (E. KulA, History of Environmental Economic Thought, Londres, Routledge, 1998, págs. 167-176).

70 Esto ya se apuntaba incluso en la «Oración sobre el estudio de las ciencias naturales»: «El hombre no verá jamás en los seres sino formas y apariencias; las sustancias y las esencias de las cosas se negarán siempre a sus sentidos [...] en vano seguirá las huellas que la naturaleza va rápidamente imprimiendo en sus formas», Gaspar Melchor de JovelLanos, «Oración sobre el estudio de las ciencias naturales [1799]», op. cit., pág. 236.

71 Como botón de muestra puede tomarse el siguiente fragmento, inscrito en un conjunto de anotaciones que delatan cierta melancolía: «La dudosa y triste luz del cielo; la extensión del mar, descubierta de tiempo en tiempo por medrosos relámpagos que rompían el lejano horizonte; el ruido sordo de las aguas, quebrantadas entre las peñas al pie de la montaña; la soledad, la calma y el silencio de todos los vivientes, hacían la situación sublime y magnífica sobre toda ponderación», Gaspar Melchor de Jovellanos, Diarios, op. cit., pág. 119, diario quinto 1793-1795, miércoles 30 de julio de 1794.

72 José Miguel Caso González, «Introducción biográfica y crítica», en Gaspar Melchor de JovelLanos, op. cit., pág. 59.

73 Gaspar Melchor de Jovellanos, «Descripción del Castillo de Bellver [1806]», op. cit., págs. 286-290.

74 Ibid., pág. 291.

75 Ibid., págs. 292-293. 
y de ciertos aspectos económicos relativos al cultivo en la zona ${ }^{76}$. En este sentido, surge otra vez en un momento dado la concepción del hombre «soberano de la Tierra», dominador y embellecedor de la naturaleza que completa la obra del Creador $^{77}$. Sin embargo, lo que caracteriza en términos generales este texto es una actitud bien distinta hacia la naturaleza, que tiene ya inspiración romántica. En primer lugar, y siempre dentro de un claro providencialismo ${ }^{78}$, hay una abierta admiración hacia la naturaleza silvestre — no domesticada por el hombre- que va acompañada de un disfrute estético y espiritual derivado de su contemplación: así por ejemplo, Jovellanos alaba su amenidad frente a la estudiada regularidad y artificio de los jardines y plantíos urbanos ${ }^{79}$, o se extasía ante un viejísimo árbol centenario $^{80}$. Y en segundo lugar, Jovellanos denuncia — de forma novedosa en su obra - la destrucción de la naturaleza, que deja «yermas y desnudas las escenas que antes hermoseaba [ésta] con sus galas»: por un lado se lamenta de la desaparición del bosque que rodeaba al castillo bajo «los golpes del hacha desoladora», dando paso a un panorama de «fealdad y tristeza», y por otro lado deplora la progresiva desaparición de la fauna, en parte debida al fin del propio bosque (pues «al paso que caían los árboles [...] le iban abandonando sus inocentes y antiguos moradores»), y en parte fruto de la práctica indiscriminada de la caza que encuentra «un bárbaro placer en la muerte y la destrucción» ${ }^{81}$.

En definitiva, lo que se ha intentado plantear en este apartado es que es posible descubrir a un Jovellanos prerromántico cuya sensibilidad ante el paisaje no difiere esencialmente de la que muestra Rousseau ${ }^{82}$ en algunos pasajes de sus Confesiones o en Las ensoñaciones del paseante solitario, ni tampoco de la que luego expresarán en sus cuadros pintores como Friedrich o Constable, o

$76 \quad$ Ibid., págs. 311-313.

7 Ibid., pág. 314.

78 «Feliz el solitario que [...] pueda gozar así del espectáculo de la naturaleza, y contemplando sus maravillas, adorar la mano omnipotente y misericordiosa que tan liberalmente las derramó por la inmensidad de los cielos y en los más escondidos ángulos de la Tierra! [...];Bendita seas, oh santa providencia de Dios, que así templas con tan fáciles y sublimes consuelos la soledad y desamparo del hombre inocente!», ibid., pág. 324.

79 Ibid., pág. 312.

80 «¡Oh árbol majestuoso, que como patriarca del valle te presentas a mi diaria meditación! ¡Allí estás ostentando a mi vista la robusta ancianidad! [...] ¡Oh cómo se enciende a tu vista mi imaginación, y qué de ilusiones no excitas en ella! [...] Tú has visto pasar rápidamente los siglos [...] tú ves ahora inmóvil la generación que respira [...] y tú verás a las que no nacieron aún pasar y atropellarse en la misma carrera», ibid., págs. 318-319. Junto a esta apreciación de la naturaleza, merece la pena destacar en esta obra la clara atracción por el pasado medieval que conecta también con el romanticismo, tal como ha señalado José Miguel Caso GonzÁlez, «Introducción biográfica y crítica», en Gaspar Melchor de Jovellanos, op. cit., pág. 57.

81 Gaspar Melchor de Jovellanos, «Oración sobre el estudio de las ciencias naturales [1799]», en Obras en prosa, op. cit., págs. 295-301.

82 Jean Jacques Rousseau, Confesiones [1782], Barcelona, Planeta, 1993; Las ensoñaciones del paseante solitario, Madrid, Alianza, 1988. 
escritores trascendentalistas como Thoreau ${ }^{83}$ o Emerson $^{84}$ — que hoy son tomados como inspiración intelectual del movimiento conservacionista americano que se desarrollaría entre 1890 y 1920_. Es más, en términos amplios la visión de la naturaleza del Jovellanos más literario cuadra a la perfección con lo que acabará conociéndose como la llamada visión romántica ${ }^{85}$, la cual es marcadamente diferente de la visión del Jovellanos economista o de la del aficionado a las ciencias naturales.

\section{Conclusión}

La actitud de Gaspar Melchor de Jovellanos frente a la naturaleza y el uso de sus recursos tiene interés, en primer lugar, por la representatividad de este autor dentro del pensamiento ilustrado español más maduro, y en segundo lugar, por ser una pieza básica a tener en cuenta cuando nos aproximamos a analizar sus ideas. Sin embargo, dicha actitud no puede entenderse plenamente sólo a través de sus escritos económicos. Como ya se indicaba en la introducción de este trabajo siguiendo a Vicent Llombart ${ }^{86}$, es difícil evaluar a Jovellanos como un «mero economista sin más» con olvido del conjunto de su obra, pues en ella hay una intencionalidad unitaria a pesar de su carácter polifacético (economía, literatura, intereses científicos, etc.). Es decir, la plena comprensión de la obra económica del escritor asturiano exige de algún modo conocer su universo ideológico, lo que a su vez implica atender a su obra en conjunto. Al hacerlo así, en el caso concreto de la actitud de Jovellanos frente a la naturaleza se descubre que ésta fue compleja e incluso contradictoria, reflejando un momento de transición — el de la ilustración tardía de finales del siglo XVIII — en el que convivían viejas y nuevas concepciones sobre la relación del hombre con su medio.

La actitud frente a la naturaleza del Jovellanos economista, aunque diferente en cierta medida de la del aficionado a las ciencias naturales, es básicamente compatible con ella. En el primer caso tenemos la postura de dominio y control

\footnotetext{
dra, 2005 .

83 Henry David Thoreau, Caminar [1862], Madrid, Ardora, 2001; Walden [1854], Madrid, Cáte-

${ }_{84}$ Ralph Waldo Emerson, Ensayo sobre la naturaleza [1844], Tegueste, Ediciones de Baile del Sol, 2000.

85 Sobre la concepción romántica de la naturaleza y el paisaje véanse Javier ArNALDo, El movimiento

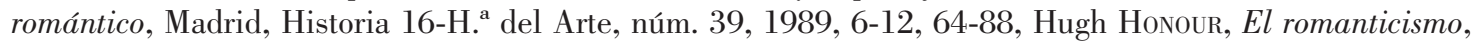
Madrid, Alianza, 1984, págs. 59-122 y Hans Joachim NeIDHARDT, «Riesgo y seguridad. Sobre la estructura y psicología del paisaje romántico», en Werner Hofmann (dir.), Caspar David Friedrich, Madrid, Museo del Prado, 1992, págs. 50-59.

86 Vicent Llombart, «Estudio introductorio», en Gaspar Melchor de Jovellanos, op. cit., págs. 20-21.
} 
activo del medio para eliminar estorbos al progreso - que conecta con la entonces novedosa idea del hombre como poderoso agente de cambio geográfico-. En el segundo caso, junto al planteamiento del sometimiento del medio apoyado en la razón y la «ciencia útil», aparece asimismo la actitud de respeto reverencial hacia «las maravillas del mundo natural» asociada a la vieja concepción providencialista del mundo, donde todo lo creado refleja la armonía divina y responde al designio de Dios de servir al hombre. Se trata de una concepción de gran tradición en la cultura española y que Jovellanos parece asumir con entusiasmo, pero que durante el siglo XVIII recibió críticas de gran calado referidas —entre otras cosas- a la inadecuación de las causas finales para comprender la naturaleza. Lo importante, de cualquier forma, es que tanto la idea del hombre como agente de cambio geográfico como la idea de designio casan perfectamente entre sí del modo en que las presenta el propio Jovellanos: el hombre es el encargado de perfeccionar o completar con sus actos la gran obra de la Creación. Además, el denominador común es una visión de la naturaleza productivista, utilitaria y - aunque por motivos distintos en cada caso- optimista, esto es, despreocupada respecto a los posibles impactos de la acción humana sobre el medio y sin plantear cautelas en relación a posibles problemas de agotamiento o degradación de los recursos. Finalmente, se trata de una visión que ensalza particularmente la naturaleza controlada, «hermoseada» por la laboriosidad humana: belleza y fertilidad van unidas.

Por su parte, la actitud del Jovellanos prerromántico, estando también marcada por el providencialismo, es, sin embargo, muy distinta. Ensalza precisamente la naturaleza incontrolada, salvaje, no domesticada por el hombre, y plantea una nueva apreciación estética del paisaje —en particular del paisaje de montaña-. Lo sublime va a ir especialmente ligado a la inmensidad inabarcable de los escenarios naturales, donde el hombre es sólo un humilde espectador que puede admirar así toda la grandeza de Dios. Jovellanos parece incluso subrayar que el hombre es parte integrante de la naturaleza —más que un ser aparte destinado a dominarla - y que ésta tiene algo de misterioso que siempre le estará vedado a la razón humana. Al margen de proporcionar un goce estético y una genuina emoción, la naturaleza posee también un gran valor espiritual, y la descripción del paisaje se convierte en realidad en una expresión de los propios estados de ánimo del espectador, una creación subjetiva. Por último, en los textos del Jovellanos prerromántico no hay rastro de la visión utilitaria de la naturaleza, y además éste llega incluso a denunciar su destrucción. En suma, dichos textos anticipan perfectamente lo que luego será la nueva sensibilidad frente a la naturaleza que caracterizará al romanticismo, y que es una de las raíces fundamentales de lo que ya en el siglo xx serán los movimientos de conservación de la naturaleza. 
Queda abierta, por tanto, una cuestión difícil: explicar cómo pudo mantener Jovellanos dos actitudes tan diferentes frente a la naturaleza, que a veces incluso llegan a aparecer en una misma obra, como ocurre en los Diarios, en las «Cartas a Ponz», o en la «Descripción del Castillo de Bellver». De hecho, las dos perspectivas - la ilustrada-utilitarista y la romántica-contemplativa- coexistieron siempre en la obra de Jovellanos, sin que hubiera cambios o evolución significativa al respecto a lo largo de su vida, al menos desde comienzos de la década de 1780. Probablemente la actitud prerromántica no pasó de ser una postura abstracta, restringida casi siempre a la expresión de sentimientos en el ámbito privado, y a veces incluso utilizada como recurso estético-literario. Sin embargo, tal como señala Casalduero ${ }^{87}$, en términos prácticos, el hombre público y el reformador social que escribe para hacer recomendaciones concretas e intentar impulsar cambios institucionales, no duda en reivindicar en todo momento la naturaleza «civilizada» en virtud de la utilidad pública y desde una optimista visión del progreso. Los planteamientos utilitarios y pragmáticos de la Ilustración se imponen entonces a posibles ensoñaciones poéticas o evasiones romántico-literarias.

87 Joaquín CASALDUero, «Las nuevas ideas económicas sobre la agricultura en el siglo dieciocho y el nuevo sentimiento de la naturaleza», La Torre, 1968, vol. XXV, núm. 61, julio - septiembre, págs. 45-60, pág. 59. 